\title{
Effect of Sowing Type and Seedbed Density on The Morphological Characteristics of Narrow-Leaved Ash Seedlings in Different Nurseries
}

\author{
Cemal FIDAN ${ }^{1} \oplus$, Ali Kemal ÖZBAYRAM ${ }^{2 *}$, Hazin Cemal GÜLTEKIN ${ }^{1} \oplus$, Hülya TAMYÜKSEL ${ }^{1}$ \\ ${ }^{1}$ Research Institute of Poplar and Fast Growing Forest Trees, İzmit, TURKEY \\ ${ }^{2}$ Düzce University, Faculty of Forestry, Department of Forest Engineering, Düzce, TURKEY \\ "Corresponding Author: alikemalozbayram@duzce.edu.tr
}

Received Date: 09.01.2019

Accepted Date: 13.11.2019

\begin{abstract}
Aim of study: The aim of this study was to investigate the effects of sowing type and seedbed density on the morphological characteristics of narrow-leaved ash (NLA) seedlings and to determine the maximum number of seedlings of the desired quality $(\mathrm{RCD} \geq 8 \mathrm{~mm}, \mathrm{HS} \geq 70 \mathrm{~cm}$ ) in two nurseries.

Area of study: This work was carried out in İzmit and Hendek (Turkey) state nurseries.

Material and methods: NLA seeds were planted in nurseries using two sowing types (straight line and square grid) and four different seedbed densities (SD: 30, 48, 99 seedlings $\mathrm{m}^{-2}$ and control). After one year of growth, height, diameter, number of roots, stem and root weights and stem-root ratio of the NLA seedlings were measured.

Main results: The seedling height and number of fine roots were positively influenced by sowing type in the İzmit seedlings, whereas sowing type did not affect seedling morphology in Hendek. The best morphological characteristics were found at SD30 for the seedlings in both nurseries. Only 5\% of the Hendek seedlings were of desired quality, while $65 \%$ were so determined in the İzmit seedlings.

Highlights: As a result, the recommended planting of 1+0-year-old bare-rooted NLA seedlings to be used in the regeneration of NLA forests would be at $30 \mathrm{~m}^{-2} \mathrm{SD}$ in the İzmit forest nursery.
\end{abstract}

Keywords: Seedbed Density, Sowing Type, Fraxinus angustifolia, Hendek, İzmit

\section{Farklı Fidanlıklarda Ekim Şekli ve Yetiştirme Sıklığının Dar Yapraklı Dişbudak Fidanlarının Morfolojik Özelliklerine Etkisi}

$\ddot{\mathbf{O} z}$

Çalışmanın amacı: Bu çalışmanın amacı ekim şeklinin ve yetiştirme sıklığının Dar yapraklı dişbudak fidanlarının morfolojik özelliklerine etkileri yanında, hangi fidanlıkta geleneksel yöntemlerle istenilen kalitede ( $\mathrm{RCD} \geq 8 \mathrm{~mm}, \mathrm{HS} \geq 70 \mathrm{~cm}$ ) en fazla sayıda fidan üretilebileceği belirlemektir.

Çalışma alanı: Bu çalışma İzmit ve Hendek Orman işletme fidanlıklarında yapıldı.

Materyal ve yöntem: Fidanlıklarda dişbudak tohumları iki ekim tipinde (çizgi ve kare ) ve dört farklı yetiştirme sıklığında (SD: 30, 48, 99 gençlik $\mathrm{m}^{-2}$ ve kontrol) ekilmiştir. Bir yıllık büyüme sonunda, boy, çap, kök sayısı, gövde ve kök ağırlıkları ve gövde-kök oranı ölçüldü. Ayrıca, fidanlıkların bazı toprak özellikleri analiz edilmiştir.

Temel sonuçlar: İzmit fidanlarının boyu ve ince kök sayısı ekim şeklinden olumlu yönde etkilenirken, ekim şekli Hendek fidanlarının morfolojisini etkilememiştir. Her iki fidanlıktaki fidanların en yüksek morfolojik özellikleri SD30'da bulunmuştur. Hendekte yetiştirilen fidanlarının sadece \% 5'i istenen kalitede iken, bu oran İzmit'te $\% 65$ olarak tespit edilmiştir.

Araştırma vurguları: Çok yoğun ve boylu diri örtü rekabeti olan dişbudak sahalarının gençleştirilmesinde kullanılacak 1+0 yaşlı ve çıplak köklü dişbudak fidanlarının İzmit orman fidanlığında 30 adet $\mathrm{m}^{-2}$ sıklıkta yetiştirilmesi önerilebilir.

Anahtar kelimeler: Yetiştirme Sıklı̆̆ı, Ekim Şekli, Fraxinus angustifolia, Hendek, İzmit 


\section{Introduction}

As one of the important broadleaved tree species in Turkey, the narrow-leaved ash (NLA, Fraxinus angustifolia Vahl.) is established in pure natural forests in the bottomlands of the Black Sea and Marmara regions. In addition, it is one of the rare tree species distributed throughout all geographic regions $(0-2000 \mathrm{~m})$ of Turkey (Yaltirik, 1978). The NLA forest areas in bottomlands are considered to be marginal (high ground water, wet and heavy clay soils, etc.) in terms of plant growth due to environmental conditions (poor drainage, heavy clayey soil, etc.) (Çiçek, E., 2004; Pliura, 1999). However, in Turkey, where poplar and alder are also found, the NLA is the fastest growing species in natural and artificial stands, with an overall average increment of approximately 13 and $23 \mathrm{~m}^{3} \mathrm{ha}^{-1}$, respectively (Kapucu et al., 1999). The yield may be higher if trees are cultivated at more suitable sites with the use of improved planting material and intensive silvicultural precautions (especially irrigation and fertilization) (Çiçek et al., 2007a).

Because of their valuable wood, NLA forests have been severely damaged for centuries. Stand structures have been degraded, and the fertile natural forests have been reduced to the point of disappearing. New plantations are being established in the degraded NLA areas. However, it is stated that these NLA plantations are low in quality, largely due to the wide planting range and the use of poor-quality seed and seedlings ( Çiçek, 2004; Çiçek \& Yılmaz, 2002).

The NLA stands on the bottomlands in Turkey have been regenerated via planting for nearly 50 years. However, the seedlings used in the plantations, especially those planted over the last decade, do not possess the desired characteristics since they were grown at very dense seedbed levels (150-250 $\left.\mathrm{m}^{-2}\right)$ in the nursery. Because seedlings of low quality and height $(<40 \mathrm{~cm})$ are used in traditional plantings in NLA areas, a significant amount of seedlings can be lost (at least 25-30\%) in the subsequent planting years (Çicek et al., 2007).

The cultivated environments are densely overgrown with high weeds, and together with the beginning of planting, the vegetation cover can reach $1.5-2 \mathrm{~m}$ in two months (Çiçek et al., 2007b). The small and lowquality seedlings used in traditional practice increase post-planting costs for complementary treatments and weed control (Çicek et al., 2007a). Seedling quality in the plantations provides important gains in volume as well as in the quality of the stand to be established (Agnihotri et al.,1989; South et al.,2001).

First-class NLA tree seedlings should have a minimum diameter of $7 \mathrm{~mm}$ and height of $40 \mathrm{~cm}$ in accordance with the Turkish Standards Institution (TSE, 1988). However, since the NLA fields where seedlings will be planted are subject to intensive weed competition, it has been stated that TSE standards are insufficient for these areas and that the root collar diameter (RCD) of the NLA seedlings should be at least $8 \mathrm{~mm}$ and height of seedlings (HS) more than $70 \mathrm{~cm}$ (Çiçek et al., 2010; Çicek et al., 2007; Çiçek et al., 2006). As $1+0$-yearold NLA seedlings can reach $12 \mathrm{~mm}$ in diameter and $80 \mathrm{~cm}$ in height (Çicek et al., 2007) and even $24 \mathrm{~mm}$ in diameter and 200 $\mathrm{cm}$ in height (Bobinac et al., 2010), they are often preferred in the re-establishment of plantations in Turkey.

In Turkey, straight-line sowing is the type most often used in forest nurseries (Gezer \& Yücedăg, 2013). Maintenance costs are less in straight-line sowing, but growth can be lower because with the competition, seedlings grow more compact (Ürgenç, 1992). Therefore, in order to allot equal growth area in the lines, a square-grid sowing type can be applied.

There are several studies on the effect of seedbed density on the morphological characteristics of NLA seedlings (Bobinac et al., 2010; Çicek et al., 2007; Kennedy Jr, 1988). Çicek et al., (2007) reported that seedbed density was effective on the morphological features of $1+0$-year-old NLA seedlings in a Forest Nursery in Düzce. Almost half of the NLA stands in Turkey (3500 ha) are distributed in the bottomlands in Sakarya Province (OGM, 2015). The seedlings used for planting in these areas are generally obtained from the İzmit and Hendek forest nurseries. However, the seedbed density and /nursery site conditions 
also affect the morphological characteristics of NLA seedlings (Bobinac et al., 2010).

Due to the marginal growth environment of NLA plantation areas and the vigorous weed competition, it was not known in which of these nurseries the traditional production of tall, high-quality seedlings could be achieved. In this context, it is important that $1+0$-year-old NLA seedlings of at least 70 $\mathrm{cm}$ HS and $8 \mathrm{~mm}$ RCD can be produced in the nursery. In addition, it is known that morphological characteristics such as RCD and HS are positively related to the survival rate and growth performance of the seedlings (Dey \& Parker, 1997; Howell \& Harrington, 1998; Jacobs et al., 2006; Ponder, 2000)

The aim of this study was to investigate the effects of two types of sowing techniques and four seedbed density (SD) rates on the morphological characteristics of NLA seedlings in the İzmit and Hendek forest nurseries, and to determine the maximum number of seedlings of the desired quality $(\mathrm{RCD} \geq 8 \mathrm{~mm}, \mathrm{HS} \geq 70 \mathrm{~cm}$ ) that can be achieved in these nurseries.

\section{Material and Methods \\ Nursery Sites}

This study was carried out in the İzmit and Hendek forest nurseries. The İzmit forest nursery $\left(29^{\circ} 54\right.$ 'E, $\left.40^{\circ} 46^{\prime} \mathrm{N}, 10 \mathrm{~m}\right)$ site consists of a bottomland area and young alluvial soils. The annual average temperature over many years has been 14.8 ${ }^{\circ} \mathrm{C}$ and for the study period in 2014 it was $16.6{ }^{\circ} \mathrm{C}$. The highest average monthly temperature observed was $29.6{ }^{\circ} \mathrm{C}$ in August and the lowest $3.30{ }^{\circ} \mathrm{C}$ in January. The average annual precipitation is $803 \mathrm{~mm}$ with a minimum rainfall of $37.6 \mathrm{~mm}$ in July (MGM, 2015).

The Hendek forest nursery $\left(30^{\circ} 40\right.$ 'E, $40^{\circ}$ $46^{\prime} \mathrm{N}, 63 \mathrm{~m}$ ) is located on a gently sloping area. Over many years, the average annual temperature has been $14.7{ }^{\circ} \mathrm{C}$ and in the project year of 2014 it was $16.4{ }^{\circ} \mathrm{C}$. The highest average monthly temperature was $29.6{ }^{\circ} \mathrm{C}$ in July and August, and the lowest was $3.0^{\circ} \mathrm{C}$ in February. The average annual rainfall over the years has been $835.3 \mathrm{~mm}$, with the lowest average rainfall of $42.3 \mathrm{~mm}$ in the month of August (MGM, 2015).

\section{Experimental Design and Applied Operations}

In both forest nurseries, the experiments were set up in randomized blocks, using the split-plot design with three replicates (Table 1). Each block in the nursery had one seedbed that was oriented in the east-west direction with a standard width of $1.2 \mathrm{~m}$. The main plot treatment was sowing type (ST, 2 levels) and the sub-plot treatment was seedbed density ( $\mathrm{SD}, 4$ levels) in each of the blocks. There were 6 plots designated as $8 \mathrm{~m}^{2}$ and 24 sub-plots as $1 \mathrm{~m}^{2}$, excluding isolation areas. The sowing spaces for seeds were $10 \times$ $10 \mathrm{~cm}, 14 \times 14 \mathrm{~cm}$, and $20 \times 20 \mathrm{~cm}$ in the square-grid sowing type. In the straight-line planting, the five-straight-line method (5row) traditionally used for growing seedlings of broadleaved tree species was applied. For both planting methods, the SD was allotted as 99,48 and 30 seedlings per square meter, while the control had more than 120 seedlings $\mathrm{m}^{-2}$. The study of Çicek et al., (2007) \& Kennedy Jr (1988) were used in the determination of these four different seedbed densities. Weed control was carried out twice in the study plots (in May and July). Irrigation was applied in each nursery program to ensure that the seedlings did not experience water stress.

The seeds used in the study were collected in autumn of 2013 from individual NLA trees growing in the İzmit region. After two months (January - March) of cold-wet stratification, the seeds were planted in the second half of March 2014.

Table 1. Experimental design of study (SD: Seedbed density, ST: Sowing type, C: Control)

\begin{tabular}{|c|c|c|c|c|c|}
\hline \multicolumn{2}{|c|}{ BLOCK 1} & \multicolumn{2}{|c|}{ BLOCK 2} & \multicolumn{2}{|c|}{ BLOCK 3} \\
\hline \multirow{4}{*}{$\vec{E}$} & SD30 & & SD99 & & SD48 \\
\hline & $\mathrm{C}$ & $\mathrm{N}$ & SD30 & E & $\mathrm{C}$ \\
\hline & SD48 & $\sqrt{n}$ & $\mathrm{C}$ & $\sqrt{n}$ & SD30 \\
\hline & SD99 & & SD48 & & SD99 \\
\hline \multirow{4}{*}{$\stackrel{\tilde{U}}{\mathrm{~N}}$} & SD99 & & SD99 & & $\mathrm{C}$ \\
\hline & SD48 & & SD48 & $N$ & SD30 \\
\hline & $\mathrm{C}$ & $\sqrt{n}$ & SD30 & $\sqrt{n}$ & SD48 \\
\hline & SD30 & & $\mathrm{C}$ & & SD99 \\
\hline
\end{tabular}

\section{Method}

To determine soil properties of the nurseries, three soil profiles were excavated 
in both nurseries and soil samples were taken from a depth level of $0-30 \mathrm{~cm}$. The soil samples were sent to the Eskisehir Soil Laboratory and their texture, $\mathrm{CaCO}_{3}$, active lime, electrical conductivity, $\mathrm{pH}$, organic matter, N, P, K, field capacity, wilting point, water availability and cation exchange capacity were analyzed.

After one growing season, the RCD of all the seedlings in the experiment was measured at a height of about $2.5 \mathrm{~cm}$ from the ground using digital calipers, and their HS was measured in meters with $\mathrm{cm}$ accuracy.

A total of 240 seedlings (10 seedlings from each trial unit) were hand-lifted from nursery plots and transported to the laboratory where their roots were washed with water. After air-drying, their number of fine roots (NFR), consisting of roots more than $2 \mathrm{~mm}$ in diameter and longer than $5 \mathrm{~cm}$, and the amount of thick roots (ATR), referring to those $2 \mathrm{~mm}$ in diameter and $5 \mathrm{~cm}$ long, were determined. The seedlings were then cut from the root collar and oven-dried at $65{ }^{\circ} \mathrm{C}$ for $48 \mathrm{~h}$. Their oven-dry weights were measured on a 0.01 precision scale to determine the dry root weight (DRW) and dry stem weight (DSW) and the root/stem ratio (RSR) was calculated.

\section{Statistical Analysis}

The soil properties of the nurseries were compared using the independent samples ttest, while the morphological characteristics of the seedlings were evaluated separately in each nursery. Two-way analysis of variance (ANOVA) was applied to determine the effect of sowing type and seedbed density on the morphological characteristics of the NLA seedlings $(P<0.05)$. Duncan's new multiple range test was used to differentiate the significance of the means. Prior to the Duncan test, the root number and root/stem ratio values had been transformed into square roots. A standard statistical software package (SPSS v.22, IBM) was used for data analysis. Before conducting the analyses, it was confirmed that the data were all normalized and the variances were homogeneous.
Results

Hendek Nursery

Sowing type had no effect on the measured morphological characteristics of the NLA seedlings in the Hendek nursery ( $P$ $>0.05$; Table 2). However, the effect of the seedbed density on RCD, HS, ATR, DRW and DSW was statistically significant $(P$ $<0.05$ ), while the effect on NFR and RSR was not significant $(P>0.05$; Table 2$)$. In addition, the effect of sowing type $\times$ seedbed density interaction on morphological characteristics was also found to be insignificant.

High morphological values were found in the NLA seedlings of the Hendek nursery grown at the lowest seedbed density (SD30). The mean RCD and HS at SD30 were 77\% and $69 \%$ greater than in the control, respectively $(P<0.05$; Table 2$)$. The RCD of seedlings at SD48, SD99 and the control were similar. The HS of seedling at SD48 and SD99 were similar and 35\% higher than in the control.

The NFR $(<2 \mathrm{~mm})$ was similar in all treatments, and was 15.5 on average. However, the ATR $(>2 \mathrm{~mm})$ was the highest in the SD30 seedlings and 3.6 times more than in the control. Similarly, the highest DRW and DSW were found at SD30, and were 2.7 and 2.4 times greater, respectively, than in the control. The RSR was found to be 1.01 for all treatments (Table 2).

\section{İzmit Nursery}

Although the effects of sowing type on the HS and NFR of seedlings in İzmit were significant, the effect on other morphological characteristics was insignificant $(P>0.05$; Table 3). In the square-grid type, the HS was 9\% shorter compared to the straight-line method, but the NFR was $26 \%$ higher. Furthermore, the effect of seedbed density on morphological characteristics, except on NFR, was significant $(P<0.05)$. The effect on morphological characteristics of the interaction of sowing type $\times$ seedbed density was also found to be insignificant $(P>0.05)$.

As in the Hendek nursery, high morphological values were found at the lowest seedbed density (SD30) in the İzmit nursery. The RCD and HS of SD48, SD99 
and the control were similar and $57 \%$ lower than for SD30 $(P<0.05$, Table 3$)$.

The NFR $(<2 \mathrm{~mm})$ of the seedlings in all treatments was similar, with an average value of 22. The ATR, DRW and DSW for SD30 were $2.7,2.1$ and 2.8 times higher than the average of the highest and the other seedbed density values, respectively. The RSR value for the other SD rates were similar, but were $33 \%$ higher than for SD30 (Table 3). 
Table 2. The effect of sowing type and seedbed density on morphological characteristics of one-year-old NLA seedlings in Hendek nursery (RCD: Root collar diameter, HS: Height of seedlings, NFR: Number of fine roots, ATR: Amount of thick roots, DRW: Dry root weight, DSW: Dry stem weight and, RSR: Root/ stem ratio)

\begin{tabular}{|c|c|c|c|c|c|c|c|}
\hline Variables & $\begin{array}{l}\text { RCD } \\
(\mathrm{mm}) \\
\end{array}$ & $\begin{array}{c}\text { HS } \\
(\mathrm{cm})\end{array}$ & $\begin{array}{c}\text { NFR } \\
\text { (number) }\end{array}$ & $\begin{array}{c}\text { ATR } \\
\text { (number) }\end{array}$ & $\begin{array}{c}\text { DRW } \\
(\mathrm{g})\end{array}$ & $\begin{array}{c}\text { DSW } \\
(\mathrm{g})\end{array}$ & RSR \\
\hline \multicolumn{8}{|l|}{ Sowing type } \\
\hline Straight line & $5.8(1.3) \mathrm{a}$ & $39.1(12.9) \mathrm{a}$ & $14.6(4.2) \mathrm{a}$ & $2.1(1.4) \mathrm{a}$ & $4.8(2.8) \mathrm{a}$ & $4.4(2.5) \mathrm{a}$ & $1.110(0.19) \mathrm{a}$ \\
\hline Square grid & $5.7(1.4) \mathrm{a}$ & $38.8(9.7) \mathrm{a}$ & 16.5 (4.5) a & $1.9(1.4) \mathrm{a}$ & $4.2(1.9) \mathrm{a}$ & $4.0(2.0) \mathrm{a}$ & $1.075(0.20) \mathrm{a}$ \\
\hline Mean & $5.7(1.3)$ & $39.0(11.2)$ & $15.5(4.4)$ & $2.0(1.4)$ & $4.5(2.4)$ & $4.2(2.2)$ & $1.092(0.19)$ \\
\hline \multicolumn{8}{|c|}{ Seedbed density $\left(\right.$ seedlings $\mathrm{m}^{2}$ ) } \\
\hline 30 & $7.3(0.9) \mathrm{a}$ & $47.2(11.4) \mathrm{a}$ & $17.5(5.7) \mathrm{a}$ & $3.2(1.5) \mathrm{a}$ & $6.9(3.0) \mathrm{a}$ & $6.4(2.1) \mathrm{a}$ & $1.070(0.24) \mathrm{a}$ \\
\hline 48 & $5.7(0.9) \mathrm{b}$ & $36.9(8.2) \mathrm{ab}$ & 15.5 (3.7) a & $1.9(1.2) \mathrm{ab}$ & $4.3(1.1) \mathrm{ab}$ & $3.7(1.6) b$ & $1.200(0.20) \mathrm{a}$ \\
\hline 99 & $5.6(1.1) \mathrm{b}$ & $42.3(12.4) \mathrm{ab}$ & $15.4(4.5) \mathrm{a}$ & $2.0(0.9) \mathrm{ab}$ & $4.3(1.7) \mathrm{ab}$ & $4.2(2.2) \mathrm{ab}$ & $1.077(0.15) \mathrm{a}$ \\
\hline Control & $4.4(0.5) \mathrm{b}$ & $29.4(4.1) b$ & $13.7(3.4) \mathrm{a}$ & $0.9(0.8) \mathrm{b}$ & $2.6(0.8) b$ & $2.6(1.0) \mathrm{b}$ & $1.024(0.17) \mathrm{a}$ \\
\hline
\end{tabular}

The parentheses indicate the standard deviation. The averages indicated by the same letter in the column are statistically insignificant $(P<0.05)$. 
Table 3. The effect of sowing type and seedbed density on morphological characteristics of one-year-old NLA seedlings in İzmit nursery (RCD: Root collar diameter, HS: Height of seedlings, NFR: Number of fine roots, ATR: Amount of thick roots, DRW: Dry root weight, DSW: Dry stem weight and, RSR: Root/stem ratio)

\begin{tabular}{|c|c|c|c|c|c|c|c|}
\hline Variables & $\begin{array}{l}\text { RCD } \\
(\mathrm{mm})\end{array}$ & $\begin{array}{l}\mathrm{HS} \\
(\mathrm{cm})\end{array}$ & $\begin{array}{c}\text { NFR } \\
\text { (number) }\end{array}$ & $\begin{array}{c}\text { ATR } \\
\text { (number) }\end{array}$ & $\begin{array}{c}\text { DRW } \\
(\mathrm{g})\end{array}$ & $\begin{array}{c}\text { DSW } \\
(\mathrm{g})\end{array}$ & RSR \\
\hline \multicolumn{8}{|l|}{ Sowing type } \\
\hline Straight line & $8.8(2.2) \mathrm{a}$ & $88.1(23.1)$ a & $19.5(4.6) \mathrm{b}$ & $1.5(1.1) \mathrm{a}$ & $11.5(5.2) \mathrm{a}$ & $16.8(10.9) \mathrm{a}$ & $0.775(0.18) \mathrm{a}$ \\
\hline Square grid & $8.6(2.4) \mathrm{a}$ & $80.5(25.1) b$ & $24.5(5.4) \mathrm{a}$ & $1.6(1.2) \mathrm{a}$ & $11.6(6.3) \mathrm{a}$ & $18.0(13.5) \mathrm{a}$ & $0.796(0.27) \mathrm{a}$ \\
\hline Mean & $8.7(2.3)$ & $84.3(23.9)$ & $22.0(5.5)$ & $1.6(1.2)$ & $11.6(5.6)$ & $17.4(12)$ & $0.785(0.22)$ \\
\hline \multicolumn{8}{|c|}{ Seedbed density (seedlings $\mathrm{m}^{2}$ ) } \\
\hline 30 & $12.0(0.9) \mathrm{a}$ & $115.9(14.6) \mathrm{a}$ & $22.4(5.4) \mathrm{a}$ & $3.0(0.7) \mathrm{a}$ & $18.9(2.3) \mathrm{a}$ & $33.5(6.4) \mathrm{a}$ & $0.575(0.11) b$ \\
\hline 48 & $8.5(1.3) b$ & $82.6(14.5) b$ & $23.5(5.8) \mathrm{a}$ & $1.4(0.6) b$ & $11.4(4.6) b$ & $15.8(9.5) b$ & $0.799(0.18) \mathrm{a}$ \\
\hline 99 & $7.3(1.1) b$ & $72.8(14.5) \mathrm{b}$ & $20.3(3.1) \mathrm{a}$ & $1.2(1.0) \mathrm{b}$ & $8.9(4.3) b$ & $12.1(8.6) \mathrm{b}$ & $0.878(0.31) \mathrm{a}$ \\
\hline Control & $7.1(1.2) b$ & $65.9(14.7) \mathrm{b}$ & $21.7(7.8) \mathrm{a}$ & $0.7(0.6) b$ & $7.1(1.9) \mathrm{b}$ & $8.2(2.9) \mathrm{b}$ & $0.889(0.11) \mathrm{a}$ \\
\hline
\end{tabular}




\section{Soil Properties of Nurseries}

Although there was a statistical difference in the sand, clay and silt content, and also cation exchange capacity of the İzmit and Hendek nursery soils, no statistical difference was found in terms of other measured soil characteristics (Table 4). Compared to the Hendek nursery, the sand ratio and cation exchange capacity of the soil of the İzmit nursery were $30 \%$ and $76 \%$ higher; however, the clay and silt content of the İzmit nursery soil was lower, respectively $(P<0.05)$. In addition, the soil of both nurseries was slightly alkaline with minimal lime and the organic matter content was very low $(1.36 \%)$.

Table 4. Some top-soil $(0-30 \mathrm{~cm})$ properties of İzmit and Hendek forest nurseries

\begin{tabular}{lll}
\hline Top soil properties & \multicolumn{1}{c}{ İzmit } & Hendek \\
\hline Sand $(\%)$ & $44.74(0.02) \mathrm{a}$ & $34.48(1.16) \mathrm{b}$ \\
\hline Clay $(\%)$ & $21.15(1.18) \mathrm{b}$ & $27.70(1.19) \mathrm{a}$ \\
\hline Silt $(\%)$ & $34.11(1.32) \mathrm{b}$ & $37.83(1.15) \mathrm{a}$ \\
\hline $\mathrm{CaCO}_{3}(\%)$ & $1.48(0.09) \mathrm{a}$ & $2.53(1.68) \mathrm{a}$ \\
\hline Active lime $(\%)$ & $0.12(0.03) \mathrm{a}$ & $0.10(0.01) \mathrm{a}$ \\
\hline $\mathrm{EC}\left(\mathrm{mS} \mathrm{cm} \mathrm{cm}^{-1}\right)$ & $0.11(0.01) \mathrm{a}$ & $0.23(0.18) \mathrm{a}$ \\
\hline $\mathrm{pH}$ & $7.87(0.07) \mathrm{a}$ & $7.91(0.19) \mathrm{a}$ \\
\hline Organic matter $(\%)$ & $1.35(0.19) \mathrm{a}$ & $1.37(0.11) \mathrm{a}$ \\
\hline $\mathrm{N}(\%)$ & $0.11(0.02) \mathrm{a}$ & $0.10(0.01) \mathrm{a}$ \\
\hline $\mathrm{P}_{2} \mathrm{O}_{5}(\mathrm{ppm})$ & $71.45(13.06) \mathrm{a}$ & $50.02(9.80) \mathrm{a}$ \\
\hline $\mathrm{K}(\mathrm{ppm})$ & $309.34(99.68) \mathrm{a}$ & $201.67(79.10) \mathrm{a}$ \\
\hline Field capacity $(\%)$ & $19.47(0.61) \mathrm{a}$ & $19.48(0.27) \mathrm{a}$ \\
\hline Wilting point $(\%)$ & $8.67(0.27) \mathrm{a}$ & $8.22(0.59) \mathrm{a}$ \\
\hline Available water content $(\%)$ & $10.81(0.35) \mathrm{a}$ & $11.27(0.35) \mathrm{a}$ \\
\hline Cation exchange capacity $(\mathrm{meq} / 100 \mathrm{~g}))$ & $24.15(0.32) \mathrm{a}$ & $13.73(0.60) \mathrm{b}$ \\
\hline
\end{tabular}

The parentheses indicate the standard deviation. The averages indicated by different letters in the line are statistically significant $(\mathrm{P}<0.05)$.

\section{Discussion}

Sowing type had no effect on the morphological characteristics of the seedlings in the Hendek nursery, while it affected the HS and NFR of the seedlings in the İzmit nursery. In the İzmit nursery, the seedlings of the straight-line sowing type had the same RCD as the ones of the square grid, although they were taller. Williams \& Stewart (2006) stated that the general morphological characteristics (such as HS, RCD and NFR) of Pinus taeda seedlings did not change according to the sowing type. The aim of square-grid sowing is to provide equal growth area for the seedlings and to obtain better quality seedlings with only a small number discarded (Barnett, 1989). However, it was ascertained that the seedlings in the straight-line cultivation were not short enough to affect the quality of the NFR. The straight-line sowing type is more desirable in nursery practice for mechanical maintenance.
The RCD and HS of seedlings increased as the seedbed density decreased in both nurseries. The highest RCD and HS values were obtained with the lowest seedbed density (SD30). Similar results have been found with NLA in Duzce (Turkey) (Çicek et al., 2007; Çiçek et al., 2011) and the Serbia Forest Nursery (Bobinac et al., 2010), and with Fraxinus pennsylvanica in the USA (Kennedy Jr, 1988). However, this finding may vary according to nursery conditions and seedling species. Alnus barbata seedlings and Quercus alba seedlings are not affected by high seedbed density (Eyuboglu, 1975; Wichman \& Coggeshall, 1983). In both nurseries, ATR, DRW and DSW increased due to decreasing seedbed density. Çicek et al., (2007), in their study of the same species, found similar results in the Düzce nursery. In addition, in eastern white pine, root length and DRW increased with decreasing seedbed density (Mullin \& Bowdery, 1977). Mullin \& Bowdery (1978) 
also reported that heavier seedlings of Pinus resinosa were obtained by decreasing seedbed density. The greater morphological development of NLA seedlings due to reduced seedbed density can be explained by the increased light, water and nutrient utilization resulting from reduced competition.

The RSR was not affected by the seedbed density in Hendek, whereas it was the lowest in the SD30 in İzmit. After root pruning, 1:1 RSR is generally accepted as the standard for seedling quality (Kennedy Jr, 1988). Although the seedlings in Hendek seemed to be more standard because they were close to 1 , because the roots were short, small amounts of the roots were cut during root pruning. On the other hand, the soil properties of the İzmit nursery were better than in Hendek, and this enabled production of higher root biomass. If the measurement had been done before the root pruning, the RSR of the İzmit seedlings would have been closer to 1. Çicek et al., (2007) reported that the RSR of seedlings in the Düzce nursery were between 1.3 and 1.7 before the root pruning. In another study, the effect of seedbed density on RSR was found to be insignificant (Kennedy Jr, 1988).

Regardless of the seedbed density, the percentage of seedling in Hendek having the desired quality $(>0.8 \mathrm{~cm} \mathrm{RCD}$ and $70 \mathrm{~cm}$ HS) was $2.3 \%$, while this amount was $31 \%$ in İzmit. According to SD30, it can be said that seedlings obtained from İzmit had higher morphological characteristics (Figure 1). The rate of obtaining quality seedlings with the best morphological characteristics at SD30 was 13 times higher in the İzmit nursery than in Hendek (Figure 2). Moreover, no seedlings of the desired quality were obtained in the control plots in Hendek.

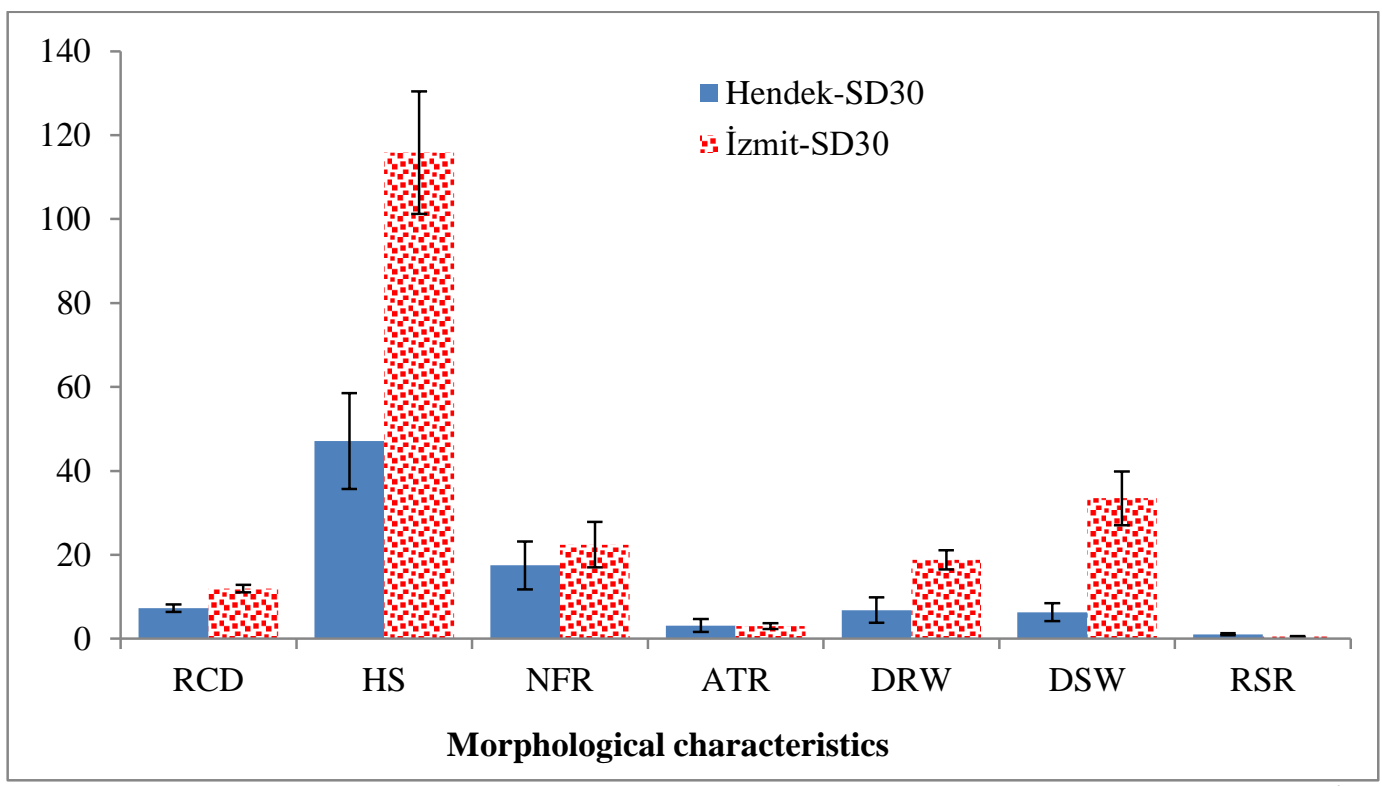

Figure 1. Comparison of morphological characteristics of seedlings in Hendek and İzmit nurseries. (RCD: Root collar diameter, HS: Height of seedlings, NFR: Number of fine roots, ATR: Amount of thick roots, DRW: Dry root weight, DSW: Dry stem weight and RSR: Root/stem ratio) 


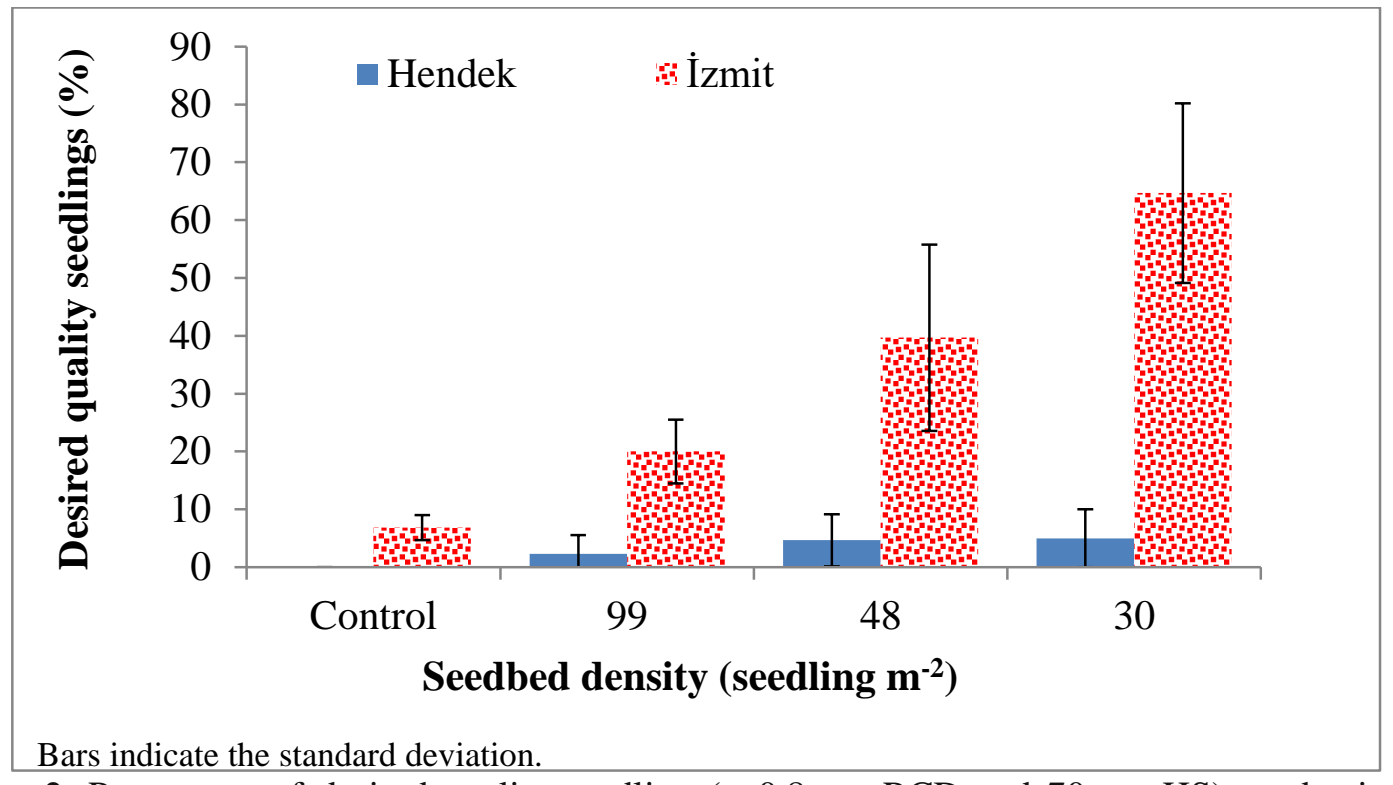

Figure 2. Percentage of desired quality seedling (> $0.8 \mathrm{~cm} \mathrm{RCD} \mathrm{and} 70 \mathrm{~cm} \mathrm{HS}$ ) production according to the seedbed density in Hendek and İzmit nurseries

Although the seeds, sowing time and the maintenance procedures used were the same, these differences in the nurseries may have caused the differences in the growing environment. Bobinac et al., (2010) stated that nursery site conditions may be more effective on NLA seedlings than seedbed density. The climatic characteristics (temperature and rainfall) of the nurseries are very close and regular irrigation is carried out according to the need of the seedlings so that they are not subjected to water stress. Accordingly, the growth difference between the nursery seedlings may have been due to differences in the nursery soils. Physical and chemical properties of the soil have a significant effect on seedling growth (Ürgenç, 1992; van den Driessche, 1984). Alameda \& Villar (2012) stated that NLA seedlings are affected by the physical properties rather than the chemical properties of the soil. Compared to the İzmit nursery, the Hendek nursery soil has high clay and low silt and sand content. For the growing of broadleaved species, it is recommended that the silt and clay content of nursery soil not exceed 35\% (Ürgenç, 1992). According to this, the İzmit nursery is more suitable for broadleaved species cultivation than the Hendek nursery (Table 3). A high clay/silt ratio $(<35 \%)$ of the soil can decrease soil permeability and aeration, and delay the heating up of the soil and development of ideal soil tillage conditions. In addition, it can cause breakage of seedling roots as a result of swelling and loss of water in the clay-textured soil (Kantarc1, 2000). Soils with high clay content are more susceptible to compaction. Soil compaction negatively affects root growth and the fine root ratio of NLA seedlings (Alameda \& Villar, 2012). The high sand content of the soil in the İzmit nursery eases seedling root propagation and results in less damage to the roots during the hand-lifting of the seedlings. The field capacity, wilting point and available water content of both nursery soils are sufficient for growing NLA seedlings.

Although the soil $\mathrm{CaCO}_{3}$ is statistically similar in both nurseries, İzmit nursery soil has less lime, and while Hendek nursery soil has a moderate amount of lime, it is suitable for growing broadleaved seedlings according to the lime classification of Çepel (1995). The soil of both nurseries is classed as very low-saline soil (EC). It is recommended that for growing broadleaved seedlings, the $\mathrm{pH}$ of forest nursery soils should be in the range of 5.8-6.5 (Ürgenç, 1992) or 6-7 (van den Driessche, 1984). The $\mathrm{pH}$ value of both nurseries was high for growing broadleaved seedlings; however, Cicek et al., (2010) states that NLA can tolerate a $\mathrm{pH}$ as high as 7.8. In addition, the $\mathrm{pH}$ has an important 
effect on the uptake of macro-nutrients, including $\mathrm{N}, \mathrm{P}$ and $\mathrm{K}$, which play an important role in plant development. The $\mathrm{N}$ mineral content in fertile soil in Turkey is reported to vary between $0.02 \%$ and $0.5 \%$ (Kacar, 2016). Accordingly, the amount of $\mathrm{N}$ of both nursery soils may be sufficient for plant growth. Cicek et al., (2010) conducted a study using different doses of NPK fertilization on $1+0$-year-old NLA seedlings in a site having $0.05 \% \mathrm{~N}, 75 \mathrm{ppm} \mathrm{P}$ and $371.5 \mathrm{ppm} \mathrm{K}$ in the soil. They stated that only $\mathrm{N}$ fertilization increased the seedling growth, whereas $\mathrm{P}$ and $\mathrm{K}$ fertilization had no significant effect, as there was sufficient $\mathrm{P}$ and $\mathrm{K}$ in the soil. Since the $\mathrm{P}$ and $\mathrm{K}$ nutrients in the soil of both nurseries in our study were quite close to those found by Cicek et al., (2010), it can be concluded that the P and $\mathrm{K}$ content of the both nursery soils may be sufficient for NLA growth. Although there was no statistical difference between the nurseries, the N, P and $\mathrm{K}$ content of the İzmit nursery soil was slightly higher than that of Hendek.

In addition, the cation exchange capacity (CEC) of soil has a significant effect on the uptake of nutrients from the soil to plants. High CEC is important in soil fertility because cations are not leached into the soil and are used in plant growth (Duryea \& Landis, 1984). The CEC of the İzmit nursery soil was $76 \%$ higher than that of the Hendek nursery. The CEC of the soil depends on the amount and type of soil colloids. Indeed, Kantarc1 (2000) states that the high clay content of the soil does not mean that the CEC will be high. The type of clay minerals, the amount of organic matter, the state of organic matter (humus types, etc.) and the amount of colloid oxides in the soil may affect the CEC. Tolay (1994) stated that in nurseries, topsoil at a depth of $0-25 \mathrm{~cm}$ should contain at least $2.0 \%$ organic matter in sandy soils and at least 3\% organic matter in clay soils. Moreover, Duryea \& Landis (1984) noted that the topsoil in a nursery should contain at least 5\% organic matter. The clay content of the soil in the Hendek nursery was higher than that of the İzmit nursery, and the amount of organic matter was low (1.35-1.36 \%) in both nurseries (Table 4).

\section{Conclusion}

Artificial regeneration and afforestation has been carried out in the Sakarya region, one of Turkey's major NLA forest areas. The 1+0-year-old NLA seedlings used for the planting are generally supplied from the Hendek and İzmit nurseries, which are closest to the NLA forest areas where there is dense weed competition. The results of the study showed that, because the soil properties (especially the physical properties) of the İzmit nursery were more suitable for growing NLA seedlings than those of the Hendek nursery, for the desired morphological characteristics, NLA seedlings aged $1+0$ years should be grown in the İzmit nursery. In the Hendek nursery, it is not possible to produce seedlings with the desired morphological characteristics at the age of $1+0$ using the traditional seedbed density. In order to produce seedlings with the desired morphological characteristics, they need to be older, but this will increase the production cost. Since $1+0$ seedlings grown at the traditional seedbed density are smaller in size, this may lead to an increase in maintenance costs after planting. Therefore, it is recommended to use SD 30 seedbed density in the İzmit nursery for highquality NLA seedlings. Intensive nursery studies of different growing and fertilization methods can be carried out to increase the number of seedlings of the desired height and quality.

Furthermore, some morphological properties of NLA seedlings were examined in this study, but genetic and physiological seedling quality parameters were not included. Comprehensive studies including these parameters can be carried out, as well as studies for enhancing the growth performance of seedlings in the field after planting.

\section{References}

Agnihotri, Y., Mishra, P., Sadhu, S. \& Singh, S. (1989). Economics of reducing rotation in Eucalyptus hybrid. Indian Journal of Forestry, 12, 2.

Alameda, D. \& Villar, R. (2012). Linking root traits to plant physiology and growth in Fraxinus angustifolia Vahl. seedlings under soil compaction conditions. Environmental 
and Experimental Botany, 79, 49-57. doi:https://doi.org/10.1016/j.envexpbot.2012.0 $\underline{1.004}$

Barnett, J. P. (1989). Seed, cultural-practices, and seedling uniformity. Forestry, 62, 95-105.

Bobinac, M., Andrasev, S. \& Šijacic-Nikolic, M. (2010). Elements of growth and structure of narrow-leaved ash (Fraxinus angustifolia Vahl) annual seedlings in the nursery on fluvisol. Periodicum biologorum, 112(3), 341351.

Çepel, N. (1995). Orman Ekolojisi. İstanbul, Türkiye: İstanbul Üniversitesi Orman Fakültesi Yayınları.

Çiçek, E., Tilki, F., Kulac, S., Yilmaz, M. \& Yilmaz, F. (2007a). Survival and growth of three hardwood species (Fraxinus angustifolia, Ulmus laevis and U. minor) on a bottomland site with heavy clay soil. Journal of Plant Science, 2(2), 233-237. doi:10.3923/jps.2007.233.237

Çiçek, E., Yilmaz, F. \& Yilmaz, M. (2010). Effect of N and NPK fertilizers on early field performance of narrow-leaved ash, Fraxinus angustifolia. Journal of Environmental Biology, 31, 109-114.

Çicek, E., Çicek, N. \& Bilir, N. (2007). Effects of seedbed density on one-year-old Fraxinus angustifolia seedling characteristics and outplanting performance. New Forests, 33(1), 81-91.

Çiçek, E. (2004). Dar yapraklı dişbudak (Fraxinus angustifolia Vahl.) plantasyonlarında bazı meşcere özelliklerinin silvikültürel yönden değerlendirilmesi. Kastamonu Üniversitesi Orman Fakültesi Dergisi, 4(2), 205-219.

Çiçek, E., Çiçek, N. \& Tilki, F. (2011). Four-year field performance of Fraxinus angustifolia Vahl. and Ulmus leavis Pall. seedlings grown at different nursery seedbed densities. Research Journal of Forestry, 5(2), 89-98. doi:10.3923/rjf.2011.89.98

Çiçek, E., Tilki, F. \& Çiçek, N. (2006). Field performance of narrow-leaved ash (Fraxinus angustifolia Vahl.) rooted cuttings and seedlings. Journal of Biological Sciences, 6(4), 750-753.

Çiçek, E., Yılmaz, F., Yılmaz, M. \& Yılmaz, S. (2007b). Dar yapraklı dişbudak (Fraxinus angustifolia Vahl.) tıraşlama alanında diri örtünün belirlenmesi ve kültür bakımı açısından değerlendirilmesi. Orman Mühendisliği Dergisi, 44(1), 25-28.

Çiçek, E. \& Yılmaz, M. (2002). The importance of Fraxinus angustifolia subsp. oxycarpa as a fast growing tree for Turkey. Paper presented at the IUFRO Meeting on Management of
Fast Growing Plantations, 11-13 September, İzmit, Turkey.

Dey, D. C. \& Parker, W. C. (1997). Morphological indicators of stock quality and field performance of red oak (Quercus rubra L.) seedlings underplanted in a central Ontario shelterwood. New Forests, 14(2), 145-156.

Duryea, M. L. \& Landis, T. D. (1984). Forest nursery manual: production of bareroot seedlings, 11: Springer Netherlands.

Eyuboglu, A. K. (1975). Kizilagacin (Alnus barbata) fidanlikta yetistirilmesinde uygun ekim sikliginin saptanmasi. Ormancllı Araştırma Enstitüsü Teknik Bülten(74), 1-22.

Gezer, A. \& Yücedağ, C. (2013). Orman ăgacl tohumlarl ve tohumdan fidan yetiştirme tekniği, 102. Isparta, Türkiye: SDÜ Orman Fakültesi Yayınları.

Howell, K. D. \& Harrington, T. B. (1998, 25-27 February). Regeneration efficiency of bareroot oak seedlings subjected to various nursery and planting treatments. Paper presented at the Proceedings of the Ninth Biennial Southern Silvicultural Research Conference, Clemson, North Carolina.

Jacobs, D., Woeste, K., Wilson, B. \& McKenna, J. (2006). Stock quality of black walnut (Juglans nigra) seedlings as affected by halfsib seed source and nursery sowing density. Acta Horticulturae, 705, 375.

Kacar, B. (2016). Fiziksel ve kimyasal toprak analizleri. Ankara, Türkiye: Nobel Akademik Yayınc1lik

Kantarc1, M. D. (2000). Toprak İlmi ( 4261/462). İstanbul, Türkiye: İstanbul Üniversitesi Orman Fakültesi.

Kapucu, F., Yavuz, H. \& Gül, A. (1999). Dişbudak meşcerelerinde hacım, bonitet endeks ve normal hasilat tablosunun düzenlenmesi. Trabzon, Turkiye: KTÜ, Fen Bilimleri Enstitüsü.

Kennedy Jr, H. E. (1988). Effects of seedbed density and row spacing on growth and nutrient concentrations of nuttall oak and green ash seedlings. Department of Agriculture, Forest Service, Southern Forest Experiment Station (USA), Research note(SO-349), 1-5.

MGM. (2015). İzmit ve Sakarya meteroloji istasyonu iklim verileri [Press release]. Retrieved from https://www.mgm.gov.tr/

Mullin, R. E. \& Bowdery, L. (1977). Effects of seedbed density and nursery fertilization on survival and growth of white spruce. The Forestry Chronicle, 53(2), 83-86. doi:10.5558/tfc53083-2

Mullin, R. E. \& Bowdery, L. (1978). Effects of nursery seedbed density and topdressing 
fertilization on survival and growth of $3+0$ red pine. Canadian Journal of Forest Research, 8(1), 30-35. doi:10.1139/x78-006

OGM. (2015). Türkiye orman varlı̆̆l. Ankara, Türkiye: Orman ve Su İşleri Bakanlığı, Orman Genel Müdürlüğü

Pliura, A. (1999). Fraxinus spp. conservation strategy. Paper presented at the Noble harwood network, Reporth of the 3rd Meeting.

Ponder, F. (2000). Survival and growth of planted hardwoods in harvested openings with firstorder lateral root differences, root-dipping, and tree shelters. Northern Journal of Applied Forestry, 17(2), 45-50.

South, D. B., Rakestraw, J. L. \& Lowerts, G. A. (2001). Early gains from planting largediameter seedlings and intensive management are additive for loblolly pine. New Forests, 22(1-2), 97-110.

Tolay, U. (1994). Yapraklı tür orman ağaçları fidan üretim tekniği. Kavak ve Hozlı Gelişen Tür Orman Ağaçlarl Araştırma Enstitüsü Dergisi, 21, 1-19.

TSE. (1988). Yapraklı orman ăgacı fidanları (TS 5624) (TS-5624). Ankara, Türkiye: Türk Standartları Enstitüsü.
Ürgenç, S. İ. (1992). A ğaç ve süs bitkileri fidanlık ve yetiştirme tekniği. İstanbul, Türkiye: İstanbul Üniversitesi Orman Fakültesi.

van den Driessche, R. (1984). Soil Fertility in Forest Nurseries. In M. L. Duryea, T. D. Landis, \& C. R. Perry (Eds.), Forestry Nursery Manual: Production of Bareroot Seedlings (63-74). Dordrecht: Springer Netherlands.

Wichman, J. R. \& Coggeshall, M. V. (1983). The effects of seedbed density and fertilization on 1-0 white oak nursery stock. Tree Planters, Notes, 34(4), 13-16.

Williams, H. M. \& Stewart, T. (2006). The effects of sower and bed density on bareroot loblolly pine seedling morphology and early height growth. Paper presented at the 13th biennial southern silvicultural research conference, Asheville, NC, USA.

Yaltirik, F. (1978). Turkiye'deki dogal Oleaceae taksonlarinin sistematik revizyonu (Taxonomic revision of the indigenous taxa within the family Oleaceae in Turkey.). $\dot{I} . \ddot{U}$. Orman Fakültesi Dergisi, 2404/250. 